\title{
Bilateral Multiple Rib Fractures and Hump-Like Shadows on Chest Roentgenogram
}

\author{
Akciğer Grafisinde Bilateral Kosta Kırığı ve Hörgüç Benzeri Gölgeler
}

Keisuke Maeda, Masashi Ohe, Haruki Shida, Tetsuya Horita, Ken Furuya

Department of Internal Medicine, JCHO Hokkaido Hospital, Sapporo, Japan

\section{ABSTRACT}

A 58-year-old female with rheumatoid arthritis (RA), osteoarthritis of the bilateral knees, thoracic vertebral compression fractures, steroid-induced osteoporosis, and immune thrombocytopenia (ITP) presented with bilateral side chest pain. She had been treated with prednisolone for RA and ITP for 10 years. On her current visit, a chest roentgenogram revealed bilateral rib fractures and hump-like shadows. A chest computed tomography scan revealed multiple rib fractures accompanied by hematoma that pressed fractured ribs into the bilateral lungs. Regarding abnormal shadows on the chest roentgenogram, blood discharge from the fractured ribs formed the hematoma, causing the hump-like shadows.

Key Words: Rheumatoid arthritis, osteoporosis, rib fractures

\section{ÖZET}

Bilateral diz osteoartriti, torakal vertebral kompresyon kırıkları, steroid kaynaklı osteoporoz ve immün trombositopeni (ITP) şikayetleri olan romatoid artritli (RA), 58 yaşında bir kadın hasta bilateral göğüs ağrısı ile başvurdu. On yıldır RA ve ITP için prednizolon tedavisi görmüştü. Hastanede çekilen akciğer grafisinde, bilateral kaburga kırığı ve hörgüç benzeri gölgeler gözlendi. Akciğer tomografisinde, çoklu kosta kırıklarına eşlik eden hematom ve hematoma bağı olarak kırık kostaların akciğerlere basısı saptandı. Akciğer grafisinde gözlenen anormal gölgelerin, kırılmış kostalardan gelen kanamaya bağlı oluşan hematomun hörgüç benzeri gölgelere neden olduğu anlaşıldı.

Anahtar Sözcükler: Romatoid artrit, osteoporoz, kosta kırıkları

Geliş Tarihi: 20.01.2018

Kabul Tarihi: 05.03.2018
A 58-year-old female with rheumatoid arthritis (RA), osteoarthritis (OA) of the bilateral knees, thoracic vertebral compression fractures, steroid-induced osteoporosis, and immune thrombocytopenia (ITP) presented with bilateral side chest pain. She had been treated with prednisolone (5-10 mg/day) for RA and ITP for 10 years. Owing to her knee pain due to RA and OA and back pain due to thoracic vertebral compression fractures, she had difficulty in walking and was almost bedridden.
On her current visit, a chest roentgenogram revealed bilateral rib fractures and hump-like shadows (Figure 1). A chest computed tomography (CT) scan revealed multiple rib fractures accompanied by hematoma that pressed fractured ribs into the bilateral lungs (Figure 2). Furthermore, a threedimensional CT scan revealed multiple rib fractures (Figure 3A, B). Regarding abnormal shadows on the chest roentgenogram, blood discharge from the fractured ribs formed the hematoma, causing the hump-like shadows. 


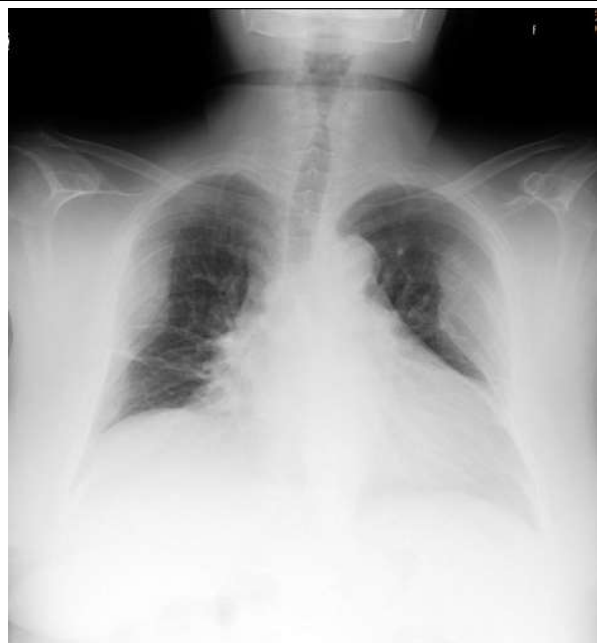

Figure 1: A chest roentgenogram reveals bilateral rib fractures and hump-like shadows.

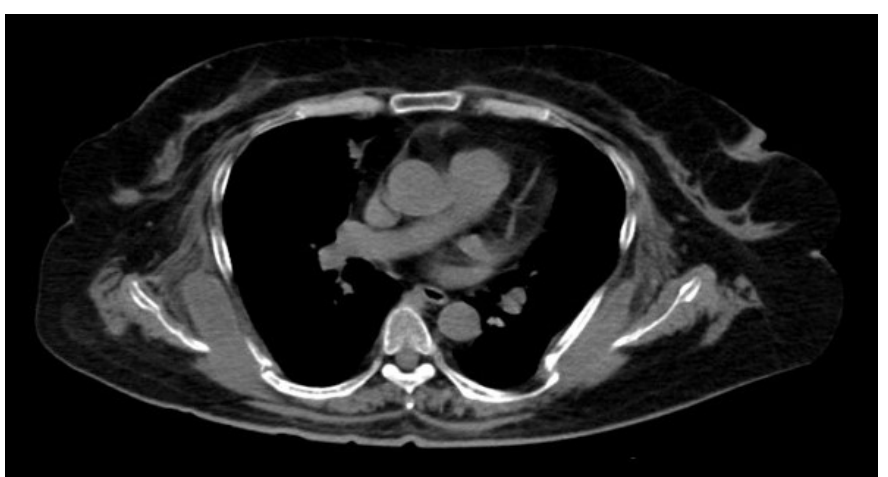

Figure 2: A chest computed tomography reveals multiple rib fractures accompanied by hematoma that presses fractured ribs into the bilateral lungs.
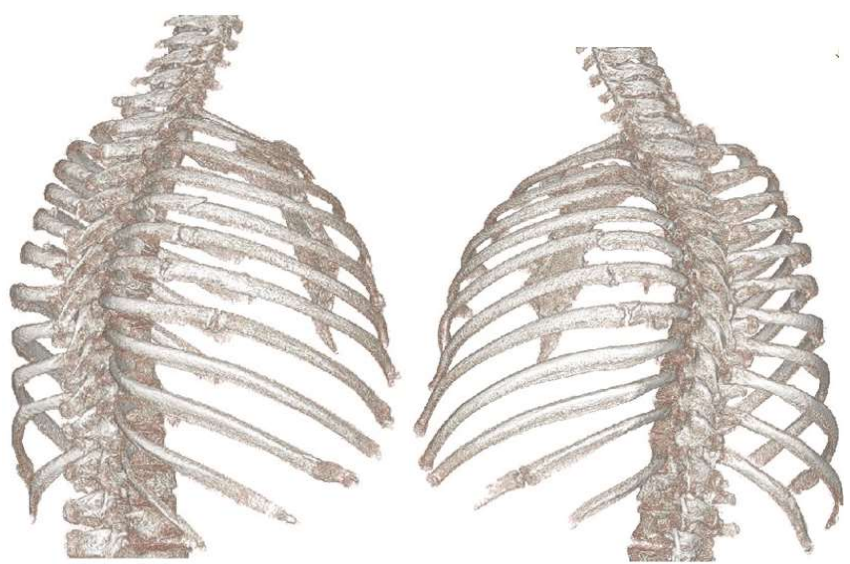

Figure 3A and 3B: A three-dimensional computed tomography reveals multiple rib fractures.
The corticosteroids often prescribed for the treatment of RA trigger a significant bone loss, resulting in osteoporosis and subsequent bone fracture. In addition, some studies demonstrate that bone loss in RA may occur as a direct result of the disease (1). Precisely, the disease activity in patients with active RA is associated with increased generalized loss of bone mass probably because of the increased release of bone-resolving cytokines, such as interleukin (IL)-1, IL-6, tumor necrosis factor- $\alpha$, and interferon- $\gamma$ (2). Hence, in the present case, multiple rib fractures might be due to steroid-induced osteoporosis and RA-associated loss of bone mass. The most common sites of osteoporotic fractures are the vertebrae, proximal femur, and distal radius (3). Conversely, Barret-Connor et al. reported that the rib is the most common site for osteoporotic nonvertebral fractures and that rib fractures account for approximately $24 \%$ of total fractures (4). Therefore, if patients with osteoporosis complain of side chest pain, the possibility of rib fractures should be considered.

\section{Conflict of interest}

No conflict of interest was declared by the authors.

\section{REFERENCES}

1.Sung YK: Risk fractures of osteoporosis in rheumatoid arthritis patients, Glucocorticoid, inactivity, or nutrient deficiencies. J Rheum Dis 2017;24:63-4. 2.El Maghraoui A, Rezqi A, Mounach A, Achemlal L, Bezza A, Ghozlani I. Prevalence and risk factors of vertebral fractures in women with rheumatoid arthritis using vertebral fracture assessment. Rheumatology (Oxford) 2010;49:1303-10.

3.Jun DS, An BK, Yu CH, Hwang KH, Paik JW. Practical use of bone scan in patients with an osteoporotic vertebral compression fracture. J Korean Med Sci 2015;30:194-8.

4.Barrett-Connor E, Nielson CM, Orwoll E, Bauer DC, Cauley JA. Epidemiology of rib fractures in older men: Osteoporotic Fractures in Men (MrOS) prospective cohort study BMJ 2010;340:c1069. 